\title{
Explorative and exploitative learning in project-based organizations: improving knowledge governance through a project management office?
}

Organizational learning, in terms of both explorative learning within projects and exploitative learning across projects, is of strategic importance for project-based organizations (PBOs) in industries involving production of complex product systems (CoPS). In this conceptual article, we discuss and reflect on how organizational learning may be addressed in PBOs by the establishment of formal knowledge governance mechanisms in a project management office (PMO). Prior literature on PMOs has discussed a broad and diverse range of PMO functions, without conceptually reflecting on their interdependencies. Here, we synthesize the literature into seven main functions. From an organizational learning perspective, we identify significant synergies among the functions of Developing and maintaining a lessonslearnt database, Developing and maintaining project management standards and methods, Consulting and education, and Strategic management. We reflect on how a PBO may establish a centralized PMO utilizing these four systemic learning-related functions as knowledge governance mechanisms, in order to facilitate explorative and exploitative learning through articulation and codification of knowledge. There are also synergies among the three remaining functions, project resource management, monitoring and control, and project portfolio management. These three functions are, however, control related and could be detrimental to place within a centralized PMO focusing on organizational learning.

Keywords: Exploration and exploitation, organizational learning, project-based organizations

\section{Introduction}

Managing the balance between exploitative and explorative learning is a critical challenge for organizations in most industries (March, 1991; Siggelkow and Levinthal, 2003). Exploration involves search, diversity, flexibility, experimentation and longterm innovation, whereas exploitation involves refinement, standardization, control, constraints and short-term efficiency (March, 1991; Gibson and Birkinshaw, 2004). For project-based organizations (PBOs), defining characteristics such as decentralization, short-term project focus, and interdependencies between project actors and their activities make it especially difficult to manage both explorative and exploitative learning (Cacciatori et al., 2011; Eriksson, 2013). While the unique, temporary and autonomous nature of projects is sometimes argued to facilitate explorative intra- project learning and innovation, these characteristics also hinder opportunities and motivation for exploitative learning across projects in the PBO (Hobday, 2000; Bakker et al., 2011). Numerous studies highlight the seemingly paradoxical challenges related to 
managing both explorative intra-project learning and exploitative inter-project learning (e.g. Keegan and Turner, 2001; Brady and Davies, 2004) and it is on this literature that this article seeks to build.

The challenge of managing exploration and exploitation is particularly relevant in PBOs involved in production of complex product systems (CoPS), such as offshore oil platforms, aeroplanes, shipbuilding, IT and mobile telephone systems, and large building and civil engineering projects (Hobday, 2000; Prencipe and Tell, 2001). In CoPS industries, innovation and explorative intra-project learning are critical aspects for developing and delivering complex and customized products that satisfy evolving customer demands. At the same time, exploitative inter-project learning is necessary to achieve efficient use of limited project resources. These kinds of projects, however, involve highly time-bound social interaction, discrete forms of non-repeatable activity, formal objectives and one-off tasks. They, thus, typically lack the strong ties, continued participation and common identities that characterize the communitybuilding effects found in localized, ongoing, and more routine work activities. Accordingly, project members often lack motivation for a retrospective analysis of their past experiences (von Zedtwitz, 2001), and have little incentive to transfer project learning to the parent organization (Swan et al., 2010; Javer-nick -Will, 2011). Indeed, the pursuit of immediate project goals mostly comes before wider and more longterm organizational goals (Bresnen et al., 2004), making inter-project learning a key challenge for PBOs (Scarbrough, Bresnen et al., 2004; Ho et al., 2011).

A key issue in balancing exploration and exploitation is the boundaries between projects and the parent organization that create strong barriers for transfer of knowledge gained in projects (Formentini and Romano, 2011). For example, innovation in PBOs is typically not performed in centralized R\&D departments but within specific projects (Blindenbach-Driessen and van den Ende, 2006). Accordingly, explorative learning first has to take place within pro- jects, then be transferred either directly to other pro- jects, or first to the parent organization and then diffused to and exploited in subsequent projects (Brady and Davies, 2004).

We take as our point of departure the interactions between the temporary project organization and the permanent organizations that resource them, and the recent claims that initiating and managing knowledge transfer between projects and the parent organization should be the responsibility of the permanent parent organization (Bakker et al., 2011). This makes it an issue of formal organizational design and governance structures. From a knowledge governance perspective, organizational structures and mechanisms play an important role in influencing and shaping learning processes involving creation, sharing and integration of knowledge across organizational levels (Foss et al., 2010; Gooderham et al., 2011).

The project management office (PMO) is one such organizational structure (Thiry and Deguire, 2007), which has been promoted as improving organizational learning (e.g. Julian, 2008; Turner and Lee-Kelley, 2013). PMOs have become increasingly common over the past 10 years, and are usually established in an attempt to improve project performance through various functions related to support, coordination and control (Desouza and Evaristo, 2006; Andersen et al., 2007). Commonly defined as an 'organizational body or entity assigned various responsibilities related to the centralized 
and coordinated management of those pro- jects under its domain' (PMI, 2008), PMOs have generated a great deal of interest among researchers and professionals in many industries. Accordingly, there is now a growing literature dealing with the many functions that PMOs might perform. Yet, it remains unclear which tasks and functions that should be included to facilitate learning processes related to exploration and exploitation; and if it could fulfil a meaningful knowledge governance role that bridges the learning boundaries between engineering projects and the permanent parent organization.

The purpose of this conceptual article is to ascertain the main PMO functions identified in the literature, and investigate to which extent they can serve as formal knowledge governance mechanisms facilitating organizational learning. After discussing our methodology, the results of an extensive literature review are presented, giving a brief overview of the PMO literature. This is followed by an elaboration of a theoretical frame- work, which draws on the three learning processes accumulation, articulation and codification presented by Zollo and Winter (2002), and positions this against the CoPS literature. The central part of the article then discusses the seven main PMO functions identified in the literature review, and whether these facilitate explorative and exploitative learning through the three learning processes. The article concludes by discussing synergies among four learning-related functions that may improve knowledge articulation and codification when implemented together in a centralized PMO and three control-related functions that share synergies, but do not support learning.

\section{Method}

Literature reviews as a genre encompass a number of different aims and related methods. These include synthetic reviews aimed at producing new knowledge (cf. Tranfield et al., 2003) and meta-reviews aimed at documenting the state of the art (e.g. Lockett et al., 2006; Glynn and Raffaelli, 2010). Meta-reviews can be further divided into systematic or comprehensive reviews and exploratory reviews, which focus on a particular theme. In this article, we follow the latter strategy with the aim of identifying publications that deal explicitly with PMOs and their functions.

We chose to search the three databases Scopus, Web of Science and EBSCOhost for the term 'project management office(s)' in title/abstract/keywords. The search for keywords in databases to sample journals in this fashion is standard practice for literature reviews. Given the relatively recent emergence of the PMO as a research object, the use of databases offers a heterogeneous and representative picture of the range of questions, topics and approaches currently being published. Searching Scopus and the Web of Science allows for most of the journals that are usually considered to be 'high impact' to be included. In addition, EBSCOhost offers a relatively independent, large and comprehensive set of databases, and provides the widest range of journals of any available database in this domain.

A first search in Scopus and the Web of Science yielded 32 relevant journal articles in English. The equivalent search in EBSCOhost (using Academic Search Premier, Business Source Complete and Engineering Source) provided an additional six articles. By relevant is here meant an academic journal article that treats the PMO as a research 
object. This excludes book reviews, editorials and short commentaries of various kinds. It also excludes numerous articles that merely give the PMO a cursory treatment. Merging the two lists gave us 38 articles explicitly focusing on various aspects of PMOs (see the appendix for a summarizing list of the 38 articles).

After this initial identification of relevant articles, we set out to identify the main functions and associated tasks that were attributed to the PMO. This analysis was undertaken in three stages: first, identifying all tasks and functions mentioned in the articles; second, creating broad categories of identified functions; and finally, comparing across all articles to establish a final categorization. In the final stage, we sought to establish functions that are both conceptually coherent and homogeneous (i.e. convergent validity), and conceptually different (i.e. discriminant validity). We ended up with a conceptual categorization of seven main functions.

\section{An overview of the PMO literature}

Much of the PMO literature is highly practice-oriented, rather normative and tends to discuss the benefits of PMOs and the reasons and driving forces for establishing them (cf. Artto et al., 2011). The articles within our sample were found to deal with one or more of the following three broad topics: (1) the benefits and effects of a PMO on project performance; (2) transformation of and changes in PMOs; and (3) PMO mandates and implementation in terms of functions and corresponding tasks. The first topic explicitly targets the effects of PMOs on the performance of projects and/or the parent organization. The findings are inconclusive. For example, in a study including 234 organizations, Dai and Wells (2004) found no statistically significant relationship between the establishment of a PMO and project performance. In contrast, in a comparative study of 90 strategic business units (SBUs) in 2 CoPS industries, Liu and Yetton (2007) found that the establishment of PMOs improved project performance in the IT industry, but not in the construction industry. This can be compared to Martin et al. (2007), who studied 129 IT projects and concluded that the presence of a PMO affects budget performance positively, but there is no effect on schedule and quality.

The second topic focuses on the nature of the PMO. This part of the literature is split between those who view PMOs as unstable entities that are regularly transformed, in terms of both organizational structure and functions (e.g. Hobbs et al., 2008; Aubry, Müller et al., 2010), and those who see them as a permanent unit in the organization. From the former perspective, PMOs are portrayed as transient entities created to solve specific issues within dynamic organizations, implying a short life expectancy (cf. Aubry, Müller et al., 2010). The transient nature of many PMOs can, in part, be explained by that stable configurations of functions which contribute with sustainable value to the parent organization have yet to be determined. However, it is also argued that the dynamic nature of PMOs and their regular transformation are necessary in order to adapt to changing circumstances, but that too short life spans and frequent transformations of the PMOs result in unsatisfactory performance (e.g. Aubry, Richer et al., 2011). Those who instead view the PMO as a permanent entity tend to argue that PMOs can build sustainable value through a long- term focus on, 
and a continuous evolvement of, their functions and tasks (e.g. Hurt and Thomas, 2009). Here, PMOs are viewed as a permanent entity placed in the organization to support its ongoing operations, like other departments, such as purchasing or marketing and sales, by focusing on core needs for which there is long-term demand (Spalek, 2012).

The third topic targets the kind of functions that PMOs incorporate. The findings in this area are heterogeneous and diverse, and the remit and tasks of the identified functions vary significantly. Some studies discuss a small number of functions. For example, Desouza and Evaristo (2006) identified two PMO archetypes, that is, administrative and knowledge intensive PMOs, and Müller, Glücker and Aubry (2013) divided the functions into the three roles of serving, controlling and partnering. Commonly when so few functions are studied, each function involves conceptually cluttered sub-tasks. Other studies have identified and discussed a very large number of functions. Hill (2004) discussed 20 functions, and Hobbs and Aubry (2007) investigated 27. However, in these cases, many functions are found to be overlapping and interconnected. In between these extremes, there are studies dis- cussing a moderate number of functions; for example, Dai and Wells (2004) and Andersen et al. (2007) investigated six main functions.

It is clear that the diverse and sometimes contradicting results within the three main PMO research topics, at least partially, are due to the studies being conducted on various types of organizations active in different industries, such as IT (e.g. Turner and Lee-Kelley, 2013), telecommunications (e.g. Müller, Glücker and Aubry, 2013), construction and real estate (e.g. Pemsel and Wiewiora, 2013) and the healthcare sector (e.g. Aubry, Richer et al., 2011). It is also clear that definitions of PMOs commonly are broad and vague, incorporating a plethora of empirically identified phenomena. Furthermore, the definitions are generally mute on the structural implications to the parent company, such as where in the organization this unit is placed, and they do little to clarify the specific functions that the PMO undertakes. Many studies have also investigated PMO functions without conceptually distinguishing between them, or reflecting on how they relate to each other. Hence, even if a broad range of PMO functions have been investigated and numerous benefits are purported, the understanding of how these functions interact and affect learning remains unclear. Hence, we here attempt to (1) review prior literature and categorize all identified tasks into main functions, and (2) conceptually discuss how these functions are inter-related and affect organizational learning.

\section{Organizational learning processes in CoPS projects}

The literature on organizational learning is well developed and embraces diverse epistemological and theoretical positions. Prior research has highlighted the importance of the learning processes that influence the relationship between learning within projects and learning in other parts of the organization (cf. Scarbrough, Swan et al., 2004; Söderlund, 2008). Here, we have chosen to follow Prencipe and Tell (2001) in adopting the influential framework developed by Zollo and Winter (2002) to reflect on how organizational learning can be enhanced in PBOs within CoPS industries. In particular, we focus on how the three main organizational learning processes identified by Zollo and Winter (2002), 
experience accumulation, knowledge articulation and knowledge codification, may enhance explorative and exploitative learning.

Experience accumulation involves development of skills based on repeated execution of similar tasks, that is, learning by doing (Prencipe and Tell, 2001). It has been argued that organizational learning in PBOs is mostly based on experience accumulation (Swan et al., 2010). For example, in a case study of two large construction projects, Scarbrough, Swan et al. (2004) found that learning was primarily based on personal experience rather than on any systematic review of previous projects. This approach was justified by the belief that no two projects are ever the same. Similar findings can be found in a host of studies and many authors pin- point that inter-project learning is mostly achieved through individuals moving from one project to another (e.g. Keegan and Turner, 2001; Swan et al., 2010). Hence, in CoPS projects, this type of exploitative learning involves reassembling and keeping key members of a project team together over a series of projects, making it possible to build on prior experience (Brady and Davies, 2004).

Knowledge articulation is related to the collective learning that occurs when individuals express and discuss their opinions and beliefs, engage in constructive confrontations, and challenge each other's view- points (Zollo and Winter, 2002), that is, learning by reflecting and discussing (Prencipe and Tell, 2001). By sharing accumulated experiences and comparing opinions among colleagues, project members can achieve an improved level of understanding of causal links between actions and their outcomes (Zollo and Winter, 2002). This communication-intensive process for knowledge sharing and integration is related to explorative learning (Söderlund, 2008; Eriksson, 2013). Such knowledge articulation becomes even more important when project complexity is high or when dealing with unexpected and extraordinary events (Enberg et al., 2006). A further example of knowledge articulation is lessons-learnt meetings in which project members collectively reflect upon their previous actions, in order to improve their understanding and eventually articulate the links between actions and their outcomes (Prencipe and Tell, 2001; Brady and Davies, 2004). This enhances exploitative learning by capturing accumulated knowledge for the benefit of future projects (Keegan and Turner, 2001; Scarbrough, Bresnen et al., 2004).

Knowledge codification occurs when project members transform their accumulated and articulated knowledge into written procedures, manuals and guide- lines (Prencipe and Tell, 2001; Zollo and Winter, 2002). Codification is an extension of articulation and refers both to the process of writing down lessons learnt, and to the outcome of the process. The codification process affects the level of understanding through learning by writing and rewriting (Zollo and Winter, 2002). Enberg et al. (2006) argue that the codification process facilitates an overall and systemic understanding among project actors, allowing for effective knowledge integration under conditions of uncertainty. As such, the codification process may enhance explorative learning by further joint development of explorative ideas. The outcome of codification, such as manuals or a database for lessons learnt, provides for knowledge storage and transfer through learning by implementing and replicating (Prencipe and Tell, 2001; Cacciatori et al., 2011), which is related to exploitative learning (Brady and Davies, 2004).

The effectiveness of each learning process is affected by the frequency, heterogeneity 
and causal ambiguity of the work task (Zollo and Winter, 2002). Hence, knowledge articulation and codification is considered more effective than experience accumulation when tasks are characterized by low frequency (i.e. a seldom performed task), high heterogeneity (i.e. the task appears novel and different each time it is executed) and high causal ambiguity (i.e. the causal links between actions and their outcomes are ambiguous due to the number and interdependence of sub-tasks) (Zollo and Winter, 2002; Enberg et al., 2006). In CoPS industries, heterogeneity is often high and frequency is low (Prencipe and Tell, 2001). As projects often differ from each other in several critical aspects, they often entail heterogeneous tasks that will not all be repeated in successive projects (Hobday, 2000). Furthermore, even in cases with moderate heterogeneity, the frequency will remain low, due to lengthy time intervals between the execution of similar tasks (Prencipe and Tell, 2001; Söderlund, 2008). In addition, CoPS projects are complex, requiring coordination of a large number of interdependent actors and their tasks (Hobday, 2000), resulting in high causal ambiguity. Due to the secharacteristics, knowledge articulation and codification serve an important purpose in inter- project learning in PBOs in CoPS industries (Prencipe and Tell, 2001; Söderlund, 2008), through either replacing or complementing experience accumulation. However, as these learning processes are difficult to implement, PBOs have been found to struggle with knowledge articulation and especially knowledge codification (Swan et al., 2010). In the next section, we there- fore discuss to what extent different PMO functions influence knowledge articulation and codification, and whether they can play a role in managing the tension between explorative and exploitative learning in PBOs.

\section{PMO functions as knowledge governance mechanisms}

Through the literature review, we identified seven main functions that are commonly performed by PMOs. Below, we discuss how these PMO functions may serve as knowledge governance mechanisms that facilitate explorative and exploitative learning in PBOs.

\section{Lessons-learnt database}

A frequently discussed PMO function is to identify, store and diffuse best practices from lessons learnt (e.g. Desouza and Evaristo, 2006; Pemsel and Wiewiora, 2013). In lessonslearnt sessions and post-project reviews, project members first put time aside for reflective discussions about what went well and what went wrong in the project (i.e. knowledge articulation) and then produce documents that are fed into a centralized database (i.e. knowledge codification) that future projects can access (Keegan and Turner, 2001). Learning from past project experience and extending the developed knowledge for reuse in future projects is related to exploitation of prior explorative learning (Keegan and Turner, 2001; Turner and Lee-Kelley, 2013).

Indeed, formal and standardized learning tools, such as post-project reviews and lessons-learnt databases, are often available in PBOs, but they are used in a tokenistic way or ignored altogether (Monteiro de Carvalho, 2013). Project managers have neither time nor motivation to use them (Scarbrough, Swan et al., 2004; Williams, 
2008; Carrillo et al., 2012). Furthermore, projects are mostly separated and timepressured, for which reason it is hard, and even illogical, to spend time documenting and transferring knowledge for the benefit of other projects (von Zedtwitz, 2001; Swan et al., 2010). When it comes to the content of the database, project members mostly focus on product knowledge, which is often unique, rather than more generalized process knowledge, which is easier to utilize in subsequent projects (Newell et al., 2006). This results in a heterogeneous database in which all documents are different and thereby difficult to share and exploit across projects (von Zedtwitz, 2001). In contrast, an external facilitator responsible for the review meeting and its documentation facilitates a coherent and systematic database that enhances interproject learning (Williams, 2008; Bakker et al., 2011). It has been argued that the PMO can play this facilitator role (Julian, 2008), and by providing a vital centralized archive of project knowledge from lessons-learnt sessions (Dai and Wells, 2004), the PBO's organizational memory can be maintained (Brady and Davies, 2004).

\section{PM standards and methods}

PM standards and methods is a commonly identified function in the literature. In Dai and Wells' (2004) study, for example, this particular function was omnipresent. Spalek (2012) similarly concluded that the strongest organizational need that PMOs were established to address was setting up and enforcing standards and methods to be used all over the organization. Standardized information and project management (PM) manuals, containing instructions on how projects are to be completed, are widely applied to deal with routine and planned tasks (Keegan and Turner, 2001; Swan et al., 2010). From a learning perspective, increased focus on standards and routines may improve exploitative learning through knowledge transfer based on codification (Keegan and Turner, 2001).

Concerns have, however, been raised that this function may contribute another layer of centralized bureaucracy that interferes with the authority of the project manager (Dai and Wells, 2004). Furthermore, the standardization of PM methods is often in opposition to the flexibility needed in the execution of projects (Aubry, Müller et al., 2010; Monteiro de Carvalho, 2013), and has been found to impede explorative learning on the more innovative projects (Keegan and Turner, 2002). It follows that standards need to be detailed enough to provide guidance, but not so excessively detailed as to hinder creativity and flexibility (Dai and Wells, 2004). The managerial challenge is, there- fore, to develop different standards and routines for different types of projects, or to ensure that they are flexible enough to be used in different contexts.

\section{Consulting and education}

Several PMO studies discuss functions related to consulting and education (e.g. Hobbs and Aubry, 2007; Kropf and Scalzi, 2008). Training and education are often mentioned in terms of providing internal or external education in order to develop basic and general PM-

related competencies (Andersen et al., 2007; Pemsel and Wiewiora, 2013). However, several authors suggest that this function should involve more specific assistance and 
mentoring, for example, in employing PM standards and methodologies (e.g. Dai and Wells, 2004). Such knowledge articulation can involve sharing prior firm-specific experience, rather than basic and general education services.

Hobday (2000) suggests that much of the required knowledge in CoPS projects is tacit and embedded in key individuals, and cannot be easily codified. Hence, knowledge sharing through social interaction is more effective than knowledge transfer through technical tools such as IT databases (cf. Inkpen and Tsang, 2005; Williams, 2008). In short, project managers often prefer face-to-face interaction instead of searching for information in documents and databases. In a study of eight drug development teams, Bresman (2013) found that in order to learn from past experiences, the project team is heavily dependent on social interaction with actors who possess the knowledge from prior experience. This is because learning from the experiences of others often involves adaptations of knowledge, to fit the context of the adopting team (Bresman, 2013). Thus, a potential role for the PMO can be to assist pro- jects through ensuring that the knowledge gained from previous experience is adapted and implemented systematically in the new project context.

\section{Strategic management}

A function offering strategic management support can take many forms, such as participating in strategic planning and aligning the project portfolio with overarching strategic objectives (Hobbs and Aubry, 2007; Aubry, Richer et al., 2011). As the pursuit of immediate project goals mostly comes before wider and more long-term strategic objectives (Bresnen et al., 2004; Swan et al., 2010), a strategic management function can guide projects by interpreting the corporate strategy and then representing the business interests of the parent organization in the project environment (Desouza and Evaristo, 2006; Monteiro de Carvalho, 2013). In this way, articulated and codified knowledge at the strategic level is transferred through knowledge articulation to the project level, affecting how projects are performed.

Another strategic management aspect concerns sharing knowledge in the opposite direction, from the project level to the strategic level. In a study of two CoPS companies, Brady and Davies (2004) found that explorative learning at the project level influenced the strategic level in terms of reorganizations and human resource strategies to enhance further exploitative learning on a broader scale. A PMO can, thus, provide a strategic link that represents the interests of the project managers at the strategic level (Hill, 2004) by enhancing learning from the project level to the strategic level. Hence, when incorporating a strategic management function, the PMO serves as a link based on knowledge sharing between the projects under its domain and top management in the parent organization. This link requires deep knowledge and experiences from both two hierarchical levels.

\section{Project resource management}

Project resource management involves assisting or managing allocation of resources, such as staff, equipment and administrative resources (Hill, 2004; Desouza and Evaristo, 2006). Of particular interest from a learning perspective is the attention 
given to the employment of project managers in the PMO (e.g. von Zedtwitz, 2001; Hurt and Thomas, 2009). Project managers can then be dispersed geographically and wander from project to project, regardless of where these are conducted (von Zedtwitz, 2001). This would definitively enhance knowledge accumulation through increased experience. However, in large PBOs with geo- graphically dispersed activities, this approach will make project managers more distant to the local and cultural specifics that surround each project. It may also increase the distance between the project managers and the other project actors, which may hamper within-project learning based on knowledge articulation.

Furthermore, resource allocation in multi-project set- tings is often challenging and problematic. Due to inter- dependencies among projects and scarce resources, disturbances and delays in one project will have negative effects on other projects as well, when personnel are redistributed among projects (Engwall and Jerbrant, 2003). Accordingly, continuous negotiations concerning access to available resources create a tough compe- tition among projects (Engwall and Jerbrant, 2003). Such competition may create arduous relationships that are detrimental for knowledge sharing between the source and the recipient (McLaughlin et al., 2008).

\section{Monitoring and controlling}

Monitoring and controlling project performance is a common PMO function (e.g. Julian, 2008; Artto et al., 2011), and PMOs are often provided with a strong control mandate over projects in order to improve cost control (Aubry, Müller et al., 2010). However, such centralized control of costs and schedule will likely increase project managers' focus on short-term project results, and reduce their motivation for knowledge sharing and interproject learning, that is, knowledge articulation and codification (Swan et al., 2010). It has also been argued that the task of monitoring and con- trolling project costs and schedule should mainly be a continuous within-project feedback process, in order to inform PM about any adjustments required to achieve project goals (Liu and Yetton, 2007).

PMOs focusing on monitoring may also create suspicion and hostility as late, overbudget or non-performing projects are confronted. In contrast, a climate characterized by psychological safety and trust is important for facilitating intra-firm knowledge sharing (Edmondson et al., 2001; Inkpen and Tsang, 2005). Hence, this function could hinder a PMO's more supportive functions (Kropf and Scalzi, 2008) due to difficulties in building a trust-based relationship focusing on organizational learning.

\section{Project portfolio management}

In the PMO literature, a function called project portfolio management (PPM) is sometimes briefly discussed (e.g. Hill, 2004; Spalek, 2012). In some studies, PPM foremost entails identifying, proposing and selecting new projects and also coordinating among projects (e.

g. Desouza and Evaristo, 2006; Artto, et al., 2011). In other studies, PPM is treated as a broader concept, also involving resource allocation and monitoring and controlling projects (e.g. Thiry and Deguire, 2007; Unger et al., 2012). Suh a brader perspective is more coherent with how this concept is treated in the mainstream PM literature, where 
portfolio management is more holistic, involving initial selection processes but foremost subsequent resource (re)allocation activities. Accordingly, Stiling Blichfeltd and Eskerod (2008) claim that PPM involves the initial screening, selection and prioritization of project proposals; the concurrent reprioritization of projects in the portfolio; and the allocation and reallocation of resources to projects according to priority.

In a study of 30 companies with multiple-project environments, Stiling Blichfeltd and Eskerod (2008) found that project portfolio managers' main challenge was to allocate and reallocate scarce resources among competing projects. Similarly, in a study of two firms with multiple projects, Engwall and Jerbrant (2003,

p. 406) found that 'project portfolio managers were overwhelmed with issues concerning prioritizing of pro- jects and redistribution of personnel from low-prioritized, or smoothly going, projects to high priority projects or projects in urgent crisis'. This aspect makes PPM a highly stressful, problematic and challenging effort of short-term troubleshooting (Stiling Blichfeltd and Eskerod, 2008). Hence, a focus on long-term organizational learning, which might be beneficial for the portfolio as a whole, will likely be sacrificed for short-term problem-solving in troubled projects (Engwall and Jerbrant, 2003).

\section{Discussion of synergies among functions}

Our literature review shows that PMOs can take on many forms. Predominantly, they are small units with limited human resources, and often perform a broad range of functions and tasks that may or may not be related to each other. Commonly, they are viewed as instable and transient entities. Although this dynamic approach may be suitable in many empirical contexts, we maintain that this is inefficient from a knowledge governance perspective. Instead, we argue that in PBOs with a long-term and stable demand for project-based work, the PMO may serve as a permanent organizational structure providing sustainable value for the parent organization (cf. Hurt and Thomas, 2009; Spalek, 2012). We therefore turn our attention to pro- viding conceptual arguments for logical and purposeful PMO configurations based on them sharing synergies critical for explorative and exploitative learning.

Several studies have pinpointed how PBOs benefit from storing knowledge acquired in one project in a centralized database for further reuse in other projects (e.g. Cacciatori et al., 2011; Formentini and Romano, 2011), and that if it is done appropriately, it will help avoid organizational amnesia (cf. Dooley et al., 2005). Likewise, as previously described, many studies have shown how PBOs frequently struggle to do this in an effective manner and how there is a divide between collecting and storing and the subsequent diffusion and adoption. Developing and maintaining a lessons-learnt database make it possible for PMOs to link intra and inter-project learning, and thereby enhance exploitation of previously explored knowledge through articulation and codification processes. This may in turn increase the benefits of investments in explorative intra-project learning. There are synergies to be found between the lessonslearnt function and that of PM standards and methods. Feldman (2000) and Edmondson et al. (2001) have, for example, shown that development and change of organizational standards and routines are enhanced by collective reflections in lessons- 
learnt sessions. As organizational standards and routines often are complex and interdependent by nature, a change and development effort requires collective reflections by participants performing the routines (Feldman, 2000; Bresman, 2013). By collecting and synthesizing lessons learnt, the PMO can gain insights into how the PM standards and methods are perceived and used by project managers in different types of projects. The PMO can thereby improve the development of the standards (Cacciatori et al., 2011), which in turn enhances managing the tension between standardization (i.e. exploitation) and flexibility and creativity (i.e. exploration). Furthermore, involvement in developing the PM methods may create a sense of commitment and ownership of the methods among project managers (Hurt and Thomas, 2009).

Following on from the above, Consulting and education could serve as a key function that involves knowledge sharing based on articulation of previously articulated (i.e. knowledge from lessons-learnt sessions) and codified knowledge (i.e. PM standards and methods), which enhance exploitative learning. By compiling and synthesizing best practice from explorative intra- project learning, the PMO can serve as a knowledge- hub responsible for sharing firm-specific knowledge.

Such knowledge sharing helps the PBO to reap the benefits of investments in explorative innovation work. Furthermore, Hurt and Thomas (2009) highlight the synergies between this function and PM standards and methods by arguing that PMOs should invest significant resources in training project managers in using the PM methods. By consulting the PMO, project actors can get more detailed and specific guidance on how to implement and use the PM standards in the particular project context at hand (Hurt and Thomas, 2009). This becomes especially important if the PM standards are new or continuously developed in order to adapt to changing circumstances (Bresnen et al., 2004). To be able to serve project actors with such context-specific guidance, the PMO needs to develop a broad as well as deep understanding of how the PM standards and methods work in various project contexts. This is achieved through conducting lessons-learnt sessions.

The strategic management function in the PMO provides a link between the project level and the strategic level (Desouza and Evaristo, 2006). This allows for explorative intra-project learning that is captured by lessons-learnt sessions to be articulated to top management and in turn provides a channel for the diffusion and implementation of explorative best practice on a broader scale through exploitative learning (Brady and Davies, 2004). There are also synergies to be found in having the strategic management function and the consulting and education activities in the PMO. Knowledge about corporate strategies and objectives could be diffused to the project level through internal PM education and by consulting projects about how to adhere to strategic objectives.

Although the PMO literature tends to distinguish between the functions of project resource management, monitoring and control, and PPM, this group of functions shares strong synergies. In fact, PPM literature does not separate these activities, since selection and prioritization among projects require considerations of resource allocation, and coordination and resource real- location among ongoing projects require monitoring and control of project progress. The selection, prioritization, resource (re)allocation and control of projects create a competitive climate, both among projects (Engwall and Jerbrant, 2003) and between the project and the unit per- forming 
these activities (Kropf and Scalzi, 2008). Such a competitive climate is detrimental for organizational learning (McLaughlin et al., 2008). In addition, the stressful urgency of first monitoring project progress and subsequently performing short-term troubleshooting and resource re-allocation in PPM impede long- term organizational learning (Engwall and Jerbrant, 2003; Stiling Blichfeltd and Eskerod, 2008). Hence, although the three control-related functions all have to be undertaken in one way or another in PBOs, it is counterproductive to place them in a centralized PMO focusing on organizationallearning.

\section{Conclusions}

The learning processes influencing the relationship between intra and inter-project learning have been identified as critical in PBOs (cf. Scarbrough, Swan et al., 2004; Söderlund, 2008). We have in this article linked this challenge to prior research on organizational learning, which emphasizes the difficulties of balancing exploration and exploitation (e.g. March, 1991). More specifically, we have highlighted the tensions between managing explorative intra-project learning and exploitative inter-project learning (cf. Cacciatori et al., 2011; Eriksson, 2013). Our point of departure has been that this makes it an issue of interactions between the temporary project organizations and the permanent organizations that resource them (cf. Winch, 2014), and that this can be approached from a knowledge governance perspective. The emerging literature on knowledge governance stresses the importance of employing appropriate knowledge governance mechanisms that interact to provide opportunities and motivation for different learning processes at different organizational levels (Foss, 2007; Gooderham et al., 2011).

Over the past ten years, PMOs have become increasingly common across a range of industries. Research has shown that these entities take on many different forms. Nonetheless, numerous benefits pertaining to their implementation have been put forward. Prevalent among these is the notion that PMOs can improve organizational learning (Julian, 2008; Turner and Lee- Kelly, 2013). Drawing on Zollo and Winter's (2002) framework of three learning processes, accumulation, articulation, and codification, we have therefore reflected on if, and how, a purposeful configuration of PMO functions may serve as formal knowledge governance mechanisms that together aid the PBO in managing the balance between explorative and exploitative learning.

Four of the seven conceptually different functions we identified through our exploratory meta-review can be considered as learning-related and could serve as knowledge governance mechanisms; Developing and maintaining a lessons-learnt database, Developing and maintaining PM standards and methods, Consulting and education, and Strategic management. These four functions are commonly found in PBOs, regardless if they are located in a PMO or not, but their effectiveness has been put into question. Our analysis shows that they are highly systemic and share synergies, based on articulation and codification of knowledge, for which reason they should be implemented together to enhance explorative and exploitative learning. In this way, we argue, the PMO can improve the reuse of collected and stored knowledge through (1) continuous development 
of codified PM standards and methods, (2) pro- viding consulting and education services (articulation) related to the use of standards and the utilization of lessons-learnt knowledge (articulation and codification) and (3) serving as a strategic link, aiding strategic management based on articulated knowledge from projects. This moves the focus away from the common practice of merely collecting and storing knowledge to actually reusing it (Formentini and Romano, 2011).

The three other functions commonly found in a PMO_-Project resource management, Monitoring and control, and PPM — we argue are more related to control than learning, as they involve controlling and coordinating resources among projects to secure that they achieve their objectives. These functions are clearly necessary and serve an important part in the functioning of the PBO. Indeed, such project control systems in many ways epitomize the PBO (Keegan and Turner, 2002). However, they stifle explorative learning (Keegan and Turner, 2002) and a compelling argument can be put forward for them not to be mixed with the four learning-related functions.

We contribute to the PMO literature by presenting conceptual reasons for why PBOs should establish a governance structure that separates the learning- related functions from the control-related ones to facilitate a stronger focus on organizational learning, which is often lacking in PBOs. Prior organization research suggests a structural separation of exploration and exploitation in different business units to facilitate high focus on both activities, which are fundamentally different and, in some aspects, contradictory (Siggelkow and Levinthal, 2003). We also contribute to literature on organizational learning in PBOs by discussing how four learning-related PMO functions can serve as formal knowledge governance mechanisms facilitating exploitative inter-project learning and diffusion of prior explorative intra-project learning. Indeed, our configuration of PMO functions is supported by Siggelkow and Levinthal's (2003) and Brady and Davies' (2004) argument that decentralized exploration should be followed by centralized exploitation to reap the benefits of investments in explorative and exploitative learning. Another contribution to this literature field is the discussion on how a purposeful configuration of PMO functions enhances knowledge articulation and codification, which is considered especially challenging in PBOs in CoPS industries (Prencipe and Tell, 2001; Swan et al., 2010).

There are also practical implications to the arguments that we have put forward. First, it follows from the analysis that for PBOs in CoPS industries, permanent and stable PMOs are more likely to facilitate organizational learning than those that are transient and dynamic. The four learning-related functions identified take time to develop and implement and, hence, PBOs need to adopt a long-term perspective when establishing PMOs focusing on organizational learning. Second, putting too many unrelated, or even contradicting, functions under the umbrella of the PMO will make it difficult to obtain synergies among systemic functions. Simply put, a high focus on control will obstruct learning. Thus, if the PMO is to form a knowledge governance structure, the functions related to learning and control should be separated into different units.

Finally, our findings also have implications for future research on all three broad research topics identified in our overview of the PMO literature. Here, we have taken the view that PMOs can fill the role of knowledge governance structures. From this perspective, it is argued that PMOs should be relatively stable entities. However, other 
strategic intentions might provide different configurations of functions and, indeed, a different need for flexibility. Hence, future research should study the effects of different configurations of functions on performance. Studying the effects of establishing a PMO (or not) on performance and aggregating across cases is too simplistic if the configuration of functions is not taken into consideration. Accordingly, a large-scale empirical test of how different configurations of functions affect performance in different empirical contexts is encouraged. Furthermore, it is worth investigating the contextual characteristics that govern the suitability of adopting stable or transient PMOs. Regarding the third topic, further empirical research on different configurations of learning-related functions and their synergies is highly relevant. We encourage case studies on how PMOs enhance interproject learning by capturing and disseminating prior intra-project learning through articulation and codification to reap benefits of purposeful configurations and create synergies among learning-related functions.

\section{Acknowledgement}

We gratefully acknowledge the financial support from Ragnar Söderbergs Stiftelse, which made this study possible.

\section{References}

Andersen, B., Henriksen, B. and Aarseth, W. (2007) Benchmarking of project management office establishment: Extracting best practices. Journal of Management in Engineering, 23(2), 97-104.

Artto, K., Kulvik, I., Poskela, J. and Turkulainen, V. (2011) The integrative role of the project management office in the front end of innovation. International Journal of Project Management, 9(4), 408-21.

Aubry, M. and Hobbs, B. (2011) A fresh look at the contribution of project management to organizational performance. Project Management Journal, 42(1), 3-16.

Aubry, M., Hobbs, B., Müller, R. and Blomquist, T. (2010) Identifying forces driving PMO changes. Project Management Journal, 41(4), 30-45.

Aubry, M., Hobbs, B. and Thuillier, D. (2007) A new frame- work for understanding organisational project management through the PMO. International Journal of Project Management, 25(3), 328-36.

Aubry, M., Hobbs, B. and Thuillier, D. (2008) Organisational project management: A historical approach to the study of PMOs. International Journal of Project Management, 26(1), 38-43.

Aubry, M., Müller, R. and Glücker, J. (2011) Exploring PMOs through community of practice theory. Project Management Journal, 42(5), 42-56.

Aubry, M., Müller, R., Hobbs, B. and Blomquist, T. (2010) Project management offices in transition. International Journal of Project Management, 28(8), 766-78. 
Aubry, M., Richer, M-C., Lavoie-Trembley, M. and Cyr, G. (2011) Pluralism in PMO performance: The case of a PMO dedicated to a major organizational transformation. Project Management Journal, 42(6), 60-77.

Bakker, R., Cambré, B., Korlaar, L. and Raab, J. (2011) Managing the project learning paradox: A set-theoretic approach toward project knowledge transfer. International Journal of Project Management, 29(5), 494-503.

Blindenbach-Driessen, F. and van den Ende, J. (2006) Innovation in project-based firms: The context dependency of success factors. Research Policy, 35(4), 545-61.

Brady, T. and Davies, A. (2004) Building project capabilities:

From exploratory to exploitative learning. Organization Studies, 25(9), 1601-21.

Bresman, H. (2013) Changing routines: A process model of vicarious group learning in pharmaceutical R\&D. Academy of Management Journal, 56(1), 35-61.

Bresnen, M., Goussevskaia, A. and Swan, S. (2004)

Embedding new management knowledge in project-based organizations. Organization Studies, 25(9), 1535-55.

Bucur, C.-M. and Onete, B. (2008) Project office - A necessity in a competitive company. Amfiteatru Economic, 10(2), 62-8.

Cacciatori, E., Tamoschus, D. and Grabher, G. (2011) Knowledge transfer across projects: Codification in crea- tive, high-tech and engineering industries. Management Learning, 43(3), 309-31.

Carrillo, P., Ruikar, K. and Fuller, P. (2012) Lessons learned practices in the UK construction sector: Current practice and proposed improvements. Engineering Project Organization Journal, 2(4), 216-30.

Curlee, W. (2008) Modern virtual project management: The effects of a centralized and decentralized project manage- ment office. Project Management Journal, 39(1), 83-96.

Dai, C. X. and Wells, W. (2004) An exploration of project management office features and their relationship to project performance. International Journal of Project Management, 22(7), 523-32.

Desouza, K. and Evaristo, R. (2006) Project management offices: A case study of knowledge-based archetypes. International Journal of Project Management, 26(5), 414-23.

Dooley, L., Lupton, G. and ÓSullivan, D. (2005) Multiple

project management: A modern competitive necessity. Journal of Manufacturing Technology Management, 16(5), 466-82.

Edmondson, A., Bohmer, R. and Pisano, G. (2001) Disrupted routines: Team learning and new technology implemen- tation in hospitals. Administrative Science Quarterly, 46(4), 685-716.

Enberg, C., Lindkvist, L. and Tell, F. (2006) Exploring the dynamics of knowledge integration: Acting an interacting in project teams. Management Learning, 37(2), 143-65.

Engwall, M. and Jerbrant, A. (2003) The resource allocation syndrome: The prime challenge of multi-project manage- ment? International Journal of Project Management, 21(6), 403-9.

Eriksson, P. E. (2013) Exploration and exploitation in project- based organizations: Development and diffusion of knowl- edge at different organizational levels in 
construction companies. International Journal of Project Management, 31(3), 333-41.

Feldman, M. (2000) Organizational routines as a source of continuous change.

Organization Science, 11(6), 611-29.

Formentini, M. and Romano, P. (2011) Using value analysis to support knowledge transfer in the multi-project setting. International Journal of Production Economics, 131(2), 545-60. Foss, N. (2007) The emergent knowledge governance approach:

Challenges and characteristics. Organization, 14(1), 29-52.

Foss, N., Husted, K. and Michailova, S. (2010) Governing knowledge sharing in organizations: Levels of analysis, governance mechanisms, and research directions. Journal of Management Studies, 47(3), 455-82.

Gibson, C. and Birkinshaw, J. (2004) The antecedents, consequences, and mediating role of organizational ambidexterity. Academy of Management Journal, 47(2), 209-26.

Glynn, M. A. and Raffaelli, R. (2010) Uncovering mechanisms of theory development in an academic field: Lessons from leadership research. Academy of Management Annals, 4(1), 359-401.

Gooderham, P., Minbaeva, D. and Pedersn, T. (2011) Governance mechanisms for the promotion of social capital for knowledge transfer in multinational corporations. Journal of Management Studies, 48(1), 123-50.

Hill, G. (2004) Evolving the project management office: A competency continuum. Information Systems Management, 21(4), 45-51.

Ho, S. P., Hsu, Y. and Lin, E. (2011) Model for knowledge- sharing strategies: A game theory analysis. Engineering Project Organization Journal, 1(1), 53-65.

Hobbs, B. and Aubry, M. (2007) A multi-phase research program investigating project management offices (PMOs): The results of phase 1. Project Management Journal, 38(1), 74-86.

Hobbs, B. and Aubry, M. (2008) An empirically grounded search for a typology of project management offices. Project Management Journal, 39(1), 69-82.

Hobbs, B., Aubry, M. and Thuillier, D. (2008) The project management office as an organisational innovation. International Journal of Project Management, 26(5), 54755.

Hobday, M. (2000) The project-based organisation: An ideal form for managing complex products and systems? Research Policy, 29(7-8), 871-93.

Hurt, M. and Thomas, J. (2009) Building value through sustainable project management offices. Project Management Journal, 40(1), 55-72.

Inkpen, A. and Tsang, E. (2005) Social capital, networks, and knowledge transfer. Academy of Management Review, 30(1), 146-65.

Isola, M., Polikaitis, A. and Laureto, R. A. (2006) Implementation of a project management office (PMO) - Experiences from Year 1. Journal of Healthcare Information Management, 20(1), 79-87.

Javernick-Will, A. (2011) Knowledge-sharing connections across geographical boundaries in global intra-firm networks. Engineering Project Organization Journal, 1(4), 239-53.

Julian, J. (2008) How project management office leaders facilitate cross-project learning and continuous improvement.

Project Management Journal, 39(3), 43-58.

Keegan, A. and Turner, R. (2001) Quantity versus quality in project-based learning 
practices. Management Learning, 32 (1), 77-98.

Keegan, A. and Turner, R. (2002) The management of innovation in project-based firms. Long Range Planning, 35(4), 367-88.

Koria, M. (2009) Building with technology, management and innovation: Challenges for Vanuatu. International Journal of Environmental Technology and Management, 10(2), 190-205. Kropf, R. and Scalzi, G. (2008) Great project management = project success. The Physician Executive, 2008(May/June), 38-40.

Lavoie-Tremblay, M., Richer, M.-C., Marchionni, C., Cyr, G., Biron, A., Aubry, M., Bonneville-Roussy, A., and Vézina, M. (2012) Implementation of evidence-based practices in the context of a redevelopment project in a Canadian healthcare organization. Journal of Nursing Scholarship, 44(4), 418-27.

Lee-Kelley, L., Turner, N. and Ward, J. (2014) Intentionally creating a community of practice to connect dispersed technical professionals. Research-Technology Management, 57(2), 44-52.

Liu, L. and Yetton, P. (2007) The contingent effects on project performance of conducting project reviews and deploying project management offices. IEEE Transactions on Engineering Management, 54(4), 789-99.

Lockett, A., Moon, J. and Visser, W. (2006) Corporate social responsibility in management research: Focus, nature, sal- ience and sources of influence. Journal of Management Studies, 43(1), 115-36.

March, J. (1991) Exploration and exploitation in organizational learning. Organization Science, 2(1), 71-87.

Martin, N., Pearson, M. and Furumo, K. (2007) IS project management: Size, practices and the project management office. The Journal of Computer Information Systems, 47(4), 52-60.

McLaughlin, S., Paton, R. and Macbeth, D. (2008) Barrier impact on organizational learning within complex organizations. Journal of Knowledge Management, 12(2), 10723.

Monteiro de Carvalho, M. (2013) An investigation of the role of communication in IT projects. International Journal of Operations \& Production Management, 34(1), 36-64.

Müller, R., Glücker, J. and Aubry, M. (2013) A relational typology of project management offices. Project Management Journal, 44(1), 59-76.

Müller, R., Glücker, J., Aubry, M., and Shao, J. (2013) Project management knowledge flows in networks of project managers and project management offices: A case study in the pharmaceutical industry. Project Management Journal, 44(2), 4-19.

Newell, S., Bresnen, M., Edelman, L., Scarbrough, H. and Swan, J. (2006) Sharing knowledge across projects: Limits to ICT-led project review practices. Management Learning, 37(2), 167-185.

Pemsel, S. and Wiewiora, A. (2013) Project management office a knowledge broker in project-based organisations. International Journal of Project Management, 31(1), 31-42.

PMI. (2008) A guide to the project management body of knowledge (PMBOK). Newton Square.

Prencipe, A. and Tell, F. (2001) Inter-project learning: Processes and outcomes of knowledge codification in project-based firms. Research Policy, 30(9), 1373-94.

Rozenes, S. and Vitner, G. (2009) The training methodology of project management office (PMO) personnel. Industrial and Commercial Training, 
41(1), 36-42.

Scarbrough, H., Bresnen, M., Edelman, L., Laurent, S., Newell, S. and Swan, J. (2004)

The processes of project- based learning: An exploratory study. Management Learning, 35(4), 491-506.

Scarbrough, H., Swan, J., Laurent, S., Bresnen, M., Edelman,

L. and Newell, S. (2004) Project-based learning and the role of learning boundaries. Organization Studies, 25(9), 1579-600.

Siggelkow, N. and Levinthal, D. (2003) Temporarily divide to conquer: Centralized, decentralized, and reintegrated organizational approaches to exploration and adaptation. Organization Science, 14(6), 650-69.

Singh, R., Keil, M. and Kasi, V. (2009) Identifying and over- coming the challenges of implementing a project management office. European Journal of Information Systems, 18(5), 409-27.

Spalek, S. (2012) The role of project management office in the multi-project environment. International Journal of Enterprise Development, 12(2), 172-88.

Spelta, A. G. and Albertin, A. L. (2012) Project management offices in the IT area: A context-discriminant model for their establishment. Informations Systems Management, 29 (1), 40-54.

Stiling Blichfeltd, B. and Eskerod, P. (2008) Project portfolio management - there's more to it than what managers enact. International Journal of Project Management, 26(4), 357-65. Swan, J., Scarbrough, H. and Newell, S. (2010) Why don't (or do) organizations learn from projects? Management Learning, 41(3), 325-44.

Söderlund, J. (2008) Competence dynamics and learning processes in project-based firms: Shifting, adapting and lever- aging. International Journal of Innovation Management, 12 (1), 41-67.

Taylor, H., Artman, E. and Woelfer, J. P. (2012) Information technology project risk management: Bridging the gap between research and practice. Journal of Information Technology, 27(1), 17-34.

Thiry, M. and Deguire, M. (2007) Recent developments in project-based organisations. International Journal of Project Management, 25(7), 649-58.

Tranfield, D., Denyer, D. and Smart, P. (2003) Towards a methodology for developing evidence-informed management knowledge by means of systematic review. British Journal of Management, 14(3), 207-22.

Turner, N. and Lee-Kelley, L. (2013) Unpacking the theory on ambidexterity: An illustrative case on the managerial architectures, mechanisms and dynamics. Management Learning, 44(2), 179-96.

Unger, B. N., Gemünden, H. G. and Aubry, M. (2012) The three roles of a project portfolio management office: Their impact on portfolio management execution and success. International Journal of Project Management, 30(5), 608-20. Williams, T. (2008) How do organizations learn lessons from projects - and do they? IEEE Transactions on Engineering Management, 55(2), 248-66.

von Zedtwitz, M. (2001) Organizational learning through post- project reviews in R\&D. R\&D Management, 32(3), 255-68. Zollo, M. and Winter, S. (2002) Deliberate learning and the evolution of dynamic capabilities. Organization Science, 13 (3), 339-51. 


\section{Appendix: Seven PMO functions identified in literature review}

\begin{tabular}{|c|c|c|c|c|c|c|c|}
\hline & $\begin{array}{l}\text { Lessons-learnt } \\
\text { database }\end{array}$ & $\begin{array}{l}\text { PM standards and } \\
\text { methods }\end{array}$ & $\begin{array}{l}\text { Consulting and } \\
\text { education }\end{array}$ & $\begin{array}{c}\text { Strategic } \\
\text { management }\end{array}$ & $\begin{array}{l}\text { Project resource } \\
\text { management }\end{array}$ & $\begin{array}{l}\text { Monitoring and } \\
\text { controlling }\end{array}$ & PPM \\
\hline $\begin{array}{l}\text { Andersen } \\
\text { et al. (2007) }\end{array}$ & - & $\begin{array}{l}\text { Establish, develop, } \\
\text { and manage } \\
\text { shared } \\
\text { methodology and } \\
\text { processes. }\end{array}$ & $\begin{array}{l}\text { Training and } \\
\text { competence } \\
\text { development. } \\
\text { Offering support and } \\
\text { consulting to } \\
\text { projects. }\end{array}$ & $\begin{array}{l}\text { Offering support } \\
\text { to project } \\
\text { owner. }\end{array}$ & - & $\begin{array}{l}\text { Quality assurance } \\
\text { and evaluations } \\
\text { of projects. }\end{array}$ & $\begin{array}{l}\text { Proposing and } \\
\text { selecting new } \\
\text { projects. } \\
\text { Contribute to the } \\
\text { governance } \\
\text { processes of } \\
\text { the projects. }\end{array}$ \\
\hline $\begin{array}{l}\text { Artto et al. } \\
\qquad(2011)\end{array}$ & $\begin{array}{l}\text { Conduct post- } \\
\text { project reviews. } \\
\text { Implement and } \\
\text { manage a } \\
\text { database of } \\
\text { lessons-learnt. } \\
\text { Identify and } \\
\text { document best } \\
\text { practices. }\end{array}$ & $\begin{array}{l}\text { Develop, implement } \\
\text { and maintain PM } \\
\text { tools, standards } \\
\text { and processes. }\end{array}$ & $\begin{array}{l}\text { Developing } \\
\text { competency in } \\
\text { personnel, } \\
\text { including training. } \\
\text { Provide mentoring for } \\
\text { PMs. } \\
\text { Provide consultations } \\
\text { to troubled projects. } \\
\text { Create PM training } \\
\text { material. }\end{array}$ & $\begin{array}{l}\text { Provide advice to } \\
\text { upper } \\
\text { management. } \\
\text { Participate in } \\
\text { strategic } \\
\text { planning. }\end{array}$ & $\begin{array}{l}\text { Recruit, select and } \\
\text { evaluate PMs. } \\
\text { Assemble project } \\
\text { assets from across } \\
\text { the organization. } \\
\text { Allocate resources to } \\
\text { different projects. }\end{array}$ & $\begin{array}{l}\text { Monitor and } \\
\text { control project } \\
\text { performance. } \\
\text { Report project } \\
\text { status to upper } \\
\text { management. }\end{array}$ & $\begin{array}{l}\text { Identify, select } \\
\text { and prioritize } \\
\text { new projects. } \\
\text { Coordinate } \\
\text { between } \\
\text { projects. } \\
\text { Manage one or } \\
\text { more portfolio } \\
\text { (s). }\end{array}$ \\
\hline
\end{tabular}

Aubry et al. This article does not explicitly mention specific PMO functions (2007) (2008)

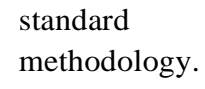
Participating in
strategic
activities.
PMs are employed in
PMO.

rovide advice to

uit, select an

control projec

(s)

Coordinate
activities and
resources.


Appendix: Continued.

\begin{tabular}{|c|c|c|c|c|c|c|c|c|}
\hline \multirow{2}{*}{\multicolumn{2}{|c|}{$\begin{array}{r} \\
\text { Aubry, Hobbs } \\
\text { et al. (2010) }\end{array}$}} & \multirow{2}{*}{$\begin{array}{l}\begin{array}{l}\text { Lessons-learnt } \\
\text { database }\end{array} \\
\text { Organizational } \\
\text { learning, } \\
\text { including lessons- } \\
\text { learnt, audits, and } \\
\text { monitoring of } \\
\text { PMO } \\
\text { performance. }\end{array}$} & $\begin{array}{l}\text { PM standards and } \\
\text { methods }\end{array}$ & $\begin{array}{l}\text { Consulting and } \\
\text { education }\end{array}$ & \multirow{2}{*}{$\begin{array}{l}\begin{array}{c}\text { Strategic } \\
\text { management }\end{array} \\
\text { Strategic } \\
\text { management, } \\
\text { including } \\
\text { strategic } \\
\text { planning and } \\
\text { benefits } \\
\text { management. }\end{array}$} & \multirow{2}{*}{$\begin{array}{l}\begin{array}{c}\text { Project resource } \\
\text { management }\end{array} \\
\text { Recruit, select, } \\
\text { evaluate and } \\
\text { determine salaries } \\
\text { for PMs. }\end{array}$} & $\begin{array}{l}\text { Monitoring and } \\
\text { controlling }\end{array}$ & PPM \\
\hline & & & $\begin{array}{l}\text { Develop and } \\
\text { implement } \\
\text { standard } \\
\text { methodologies, } \\
\text { processes, and } \\
\text { tools. }\end{array}$ & $\begin{array}{l}\text { Develop the } \\
\text { competency of } \\
\text { project personnel, } \\
\text { including training } \\
\text { and mentoring. }\end{array}$ & & & $\begin{array}{l}\text { Monitor and } \\
\text { control project } \\
\text { performance. }\end{array}$ & $\begin{array}{l}\text { Multi-PM, } \\
\text { including } \\
\text { program and } \\
\text { portfolio } \\
\text { management, } \\
\text { coordination } \\
\text { and allocation } \\
\text { of resources } \\
\text { among } \\
\text { projects. }\end{array}$ \\
\hline $\begin{array}{l}\text { Aubry, } \mathrm{M} \\
\text { et al. (2 }\end{array}$ & üller & $\begin{array}{l}\text { Organizational } \\
\text { learning. }\end{array}$ & $\begin{array}{l}\text { Develop and } \\
\text { implement } \\
\text { standards and } \\
\text { competences. }\end{array}$ & $\begin{array}{l}\text { Develop and } \\
\text { implement } \\
\text { standards and } \\
\text { competences. }\end{array}$ & $\begin{array}{l}\text { Strategic } \\
\text { management. }\end{array}$ & $\begin{array}{l}\text { Recruit, select, } \\
\text { evaluate and } \\
\text { determine salaries } \\
\text { for PMs. }\end{array}$ & $\begin{array}{l}\text { Monitor and } \\
\text { control project } \\
\text { performance. }\end{array}$ & Multi-PM. \\
\hline $\begin{array}{r}\text { Aubry an } \\
\text { Hobbs } \\
\text { (2011) }\end{array}$ & & - & $\begin{array}{l}\text { Standardization of } \\
\text { methods and } \\
\text { processes. } \\
\text { Development and } \\
\text { dissemination of } \\
\text { PM methodology. }\end{array}$ & $\begin{array}{l}\text { Development of } \\
\text { competences. } \\
\text { Training in PM. } \\
\text { Coaching of PMs. }\end{array}$ & - & $\begin{array}{l}\text { Management of } \\
\text { human resources. } \\
\text { Allocation of } \\
\text { resources. } \\
\text { Participating in the } \\
\text { career paths of } \\
\text { PMs. }\end{array}$ & $\begin{array}{l}\text { Monitor and } \\
\text { control the } \\
\text { performance of } \\
\text { projects. } \\
\text { Control of costs, } \\
\text { schedule and } \\
\text { scope. }\end{array}$ & $\begin{array}{l}\text { Involvement in } \\
\text { portfolio } \\
\text { management. }\end{array}$ \\
\hline $\begin{array}{l}\text { Aubry, } \\
\text { Müller } \\
\text { et al. } \\
(2011)\end{array}$ & $\begin{array}{r}\text { Post } \\
\text { re } \\
\text { Man } \\
\text { pr } \\
\text { do } \\
\text { Impl } \\
\mathrm{m} \\
\text { da } \\
\text { les }\end{array}$ & $\begin{array}{l}\text {-project } \\
\text { views. } \\
\text { age archives of } \\
\text { oject } \\
\text { cumentation. } \\
\text { ement and } \\
\text { anage a } \\
\text { tabase of } \\
\text { sons-learnt. }\end{array}$ & $\begin{array}{l}\text { methodology } \\
\text { nd processes. }\end{array}$ & $\begin{array}{l}\text { eminating best } \\
\text { ractices in group } \\
\text { arning situations. }\end{array}$ & - & \multicolumn{2}{|c|}{$\begin{array}{l}\text { Conduct project } \\
\text { audits. }\end{array}$} & $\begin{array}{l}\text { ortfolio } \\
\text { management. }\end{array}$ \\
\hline
\end{tabular}




\begin{tabular}{|c|c|c|c|c|c|c|c|}
\hline $\begin{array}{c}\text { Aubry, Richer } \\
\text { et al. } \\
(2011)\end{array}$ & $\begin{array}{l}\text { Conduct post- } \\
\text { project reviews. } \\
\text { Manage a database } \\
\text { of lessons-learnt. } \\
\text { Manage project } \\
\text { documentation } \\
\text { archives. }\end{array}$ & $\begin{array}{l}\text { Develop and } \\
\text { implement a } \\
\text { standard } \\
\text { methodology. }\end{array}$ & $\begin{array}{l}\text { Develop personnel } \\
\text { competency, } \\
\text { including training. } \\
\text { Provide mentoring for } \\
\text { PMs. }\end{array}$ & $\begin{array}{l}\text { Provide advice to } \\
\text { upper } \\
\text { management. } \\
\text { Participate in } \\
\text { strategic } \\
\text { planning. }\end{array}$ & $\begin{array}{l}\text { Allocate resources } \\
\text { between projects. } \\
\text { Recruit, select, } \\
\text { evaluate and } \\
\text { determine salaries } \\
\text { for PMs. }\end{array}$ & $\begin{array}{l}\text { Monitor and } \\
\text { control project } \\
\text { performance. } \\
\text { Conduct project } \\
\text { audits. } \\
\text { Report project } \\
\text { status to upper } \\
\text { management. }\end{array}$ & $\begin{array}{l}\text { Identify, select } \\
\text { and prioritize } \\
\text { new projects. } \\
\text { Coordinate } \\
\text { between } \\
\text { projects. } \\
\text { Manage one or } \\
\text { more portfolio } \\
\text { (s). }\end{array}$ \\
\hline $\begin{array}{l}\text { Bucur and } \\
\text { Onete } \\
(2008)\end{array}$ & $\begin{array}{l}\text { Lessons-learnt } \\
\text { information } \\
\text { system. }\end{array}$ & $\begin{array}{l}\text { Establishing and } \\
\text { maintaining PM } \\
\text { standards. } \\
\text { Developing and } \\
\text { maintaining } \\
\text { processes and } \\
\text { methodologies. }\end{array}$ & $\begin{array}{l}\text { PM training. } \\
\text { Tailoring standardized } \\
\text { courses. } \\
\text { Consulting and } \\
\text { mentoring PMs. }\end{array}$ & - & $\begin{array}{l}\text { Assigning specific } \\
\text { project manager to } \\
\text { specific projects. }\end{array}$ & $\begin{array}{l}\text { Control of project } \\
\text { cost and } \\
\text { scheduling. }\end{array}$ & \\
\hline $\begin{array}{l}\text { Curlee, } \\
\text { (2008) }\end{array}$ & $\begin{array}{l}\text { Lessons-learnt } \\
\text { database. }\end{array}$ & $\begin{array}{l}\text { Maintaining PM } \\
\text { methods and } \\
\text { standardized } \\
\text { processes. }\end{array}$ & $\begin{array}{l}\text { Responsible for } \mathrm{PM} \\
\text { training. }\end{array}$ & - & - & - & - \\
\hline $\begin{array}{l}\text { Dai and Wells } \\
\text { (2004) }\end{array}$ & $\begin{array}{l}\text { Developing and } \\
\text { maintaining } \\
\text { project historical } \\
\text { archives. }\end{array}$ & $\begin{array}{l}\text { Developing and } \\
\text { maintaining PM } \\
\text { standards and } \\
\text { methods. }\end{array}$ & $\begin{array}{l}\text { Providing PM } \\
\text { consulting and } \\
\text { mentoring. } \\
\text { Providing or arranging } \\
\text { PM training. }\end{array}$ & - & $\begin{array}{l}\text { Providing human } \\
\text { resource/staffing } \\
\text { assistance. } \\
\text { Identifying proper } \\
\text { person to manage } \\
\text { project. }\end{array}$ & - & - \\
\hline $\begin{array}{l}\text { Desouza and } \\
\text { Evaristo } \\
\text { (2006) }\end{array}$ & $\begin{array}{l}\text { Project knowledge } \\
\text { management. } \\
\text { Leveraging } \\
\text { knowledge and } \\
\text { lessons learnt. } \\
\text { Ensure knowledge } \\
\text { sharing among } \\
\text { projects. }\end{array}$ & $\begin{array}{l}\text { Project processes and } \\
\text { procedures. } \\
\text { Defining PM } \\
\text { methodology. }\end{array}$ & $\begin{array}{l}\text { Training for project } \\
\text { teams. } \\
\text { Managing the } \\
\text { educational } \\
\text { requirements for } \\
\text { PMs. }\end{array}$ & $\begin{array}{l}\text { Ensure that } \\
\text { projects are } \\
\text { aligned with } \\
\text { strategic } \\
\text { objectives of } \\
\text { the } \\
\text { organization. }\end{array}$ & $\begin{array}{l}\text { Project resources. } \\
\text { Managing the } \\
\text { staffing, } \\
\text { equipment, office } \\
\text { space and other } \\
\text { resources. }\end{array}$ & $\begin{array}{l}\text { Project financial } \\
\text { management. } \\
\text { Ensuring that } \\
\text { projects are } \\
\text { financially } \\
\text { viable. } \\
\text { Conducting } \\
\text { project } \\
\text { evaluations. } \\
\text { Identify runaway } \\
\text { projects. }\end{array}$ & $\begin{array}{l}\text { PPM. } \\
\text { Coordinating } \\
\text { among } \\
\text { multiple } \\
\text { projects. }\end{array}$ \\
\hline
\end{tabular}


Appendix: Continued.

\begin{tabular}{|c|c|c|c|c|c|c|c|}
\hline & $\begin{array}{l}\text { Lessons-learnt } \\
\text { database }\end{array}$ & $\begin{array}{l}\text { PM standards and } \\
\text { methods }\end{array}$ & $\begin{array}{l}\text { Consulting and } \\
\text { education }\end{array}$ & $\begin{array}{c}\text { Strategic } \\
\text { management }\end{array}$ & $\begin{array}{c}\text { Project resource } \\
\text { management }\end{array}$ & $\begin{array}{l}\text { Monitoring and } \\
\text { controlling }\end{array}$ & PPM \\
\hline Hill (2004) & $\begin{array}{l}\text { Project knowledge } \\
\text { management. }\end{array}$ & $\begin{array}{l}\text { PM standards, tools } \\
\text { and methodology. }\end{array}$ & $\begin{array}{l}\text { Training and } \\
\text { education. } \\
\text { Team development. } \\
\text { Mentoring. }\end{array}$ & $\begin{array}{l}\text { Business } \\
\text { performance. }\end{array}$ & $\begin{array}{l}\text { Resource } \\
\text { management. } \\
\text { Career development. } \\
\text { Facilities and } \\
\text { equipment } \\
\text { support. }\end{array}$ & $\begin{array}{l}\text { Project auditing. } \\
\text { Project recovery. } \\
\text { Assessment. }\end{array}$ & PPM. \\
\hline $\begin{array}{l}\text { Hobbs and } \\
\text { Aubry } \\
\text { (2007) }\end{array}$ & $\begin{array}{l}\text { Manage archives of } \\
\text { project } \\
\text { documentation. } \\
\text { Conduct post- } \\
\text { project reviews. } \\
\text { Manage database of } \\
\text { lessons-learnt. } \\
\text { Implement and } \\
\text { manage risk } \\
\text { database. }\end{array}$ & $\begin{array}{l}\text { Develop and } \\
\text { implement a } \\
\text { standard } \\
\text { methodology. } \\
\text { Provide a set of tools } \\
\text { without an effort to } \\
\text { standardize. }\end{array}$ & $\begin{array}{l}\text { Develop competency } \\
\text { of personnel, } \\
\text { including training. } \\
\text { Provide mentoring for } \\
\text { PMs. }\end{array}$ & $\begin{array}{l}\text { Benefits } \\
\text { management. } \\
\text { Participate in } \\
\text { strategic } \\
\text { planning. } \\
\text { Provide advice to } \\
\text { upper } \\
\text { management. }\end{array}$ & $\begin{array}{l}\text { Allocate resources } \\
\text { between projects. } \\
\text { Recruit, select, } \\
\text { evaluate, and } \\
\text { determine salaries } \\
\text { for project } \\
\text { managers. }\end{array}$ & $\begin{array}{l}\text { Report project } \\
\text { status to upper } \\
\text { management. } \\
\text { Monitor and } \\
\text { control of } \\
\text { project } \\
\text { performance. } \\
\text { Implement and } \\
\text { operate a } \\
\text { project } \\
\text { information } \\
\text { system. } \\
\text { Develop and } \\
\text { maintain a } \\
\text { project } \\
\text { scoreboard. } \\
\text { Conduct project } \\
\text { audits. }\end{array}$ & $\begin{array}{l}\text { Coordinate } \\
\text { between } \\
\text { projects. } \\
\text { Manage one or } \\
\text { more } \\
\text { portfolios. } \\
\text { Identify, select } \\
\text { and prioritize } \\
\text { new projects. }\end{array}$ \\
\hline $\begin{array}{l}\text { Hobbs and } \\
\text { Aubry } \\
\text { (2008) }\end{array}$ & - & - & - & - & $\begin{array}{l}\text { Employing PMs and } \\
\text { allocating them to } \\
\text { projects. }\end{array}$ & - & - \\
\hline $\begin{array}{l}\text { Hobbs et al. } \\
\text { (2008) }\end{array}$ & - & $\begin{array}{l}\text { Developing and } \\
\text { standardizing PM } \\
\text { methodology and } \\
\text { processes. }\end{array}$ & - & $\begin{array}{l}\text { Responsibility to } \\
\text { align projects } \\
\text { to business } \\
\text { strategy. }\end{array}$ & Resource allocation. & $\begin{array}{l}\text { Controlling } \\
\text { projects. }\end{array}$ & $\begin{array}{l}\text { Portfolio } \\
\text { management. }\end{array}$ \\
\hline $\begin{array}{l}\text { Hurt and } \\
\text { Thomas } \\
\text { (2009) }\end{array}$ & $\begin{array}{l}\text { Portal to access } \\
\text { project material } \\
\text { and archives. }\end{array}$ & $\begin{array}{l}\text { Developing PM } \\
\text { methodology. } \\
\text { Basic processes, tools } \\
\text { d templates. }\end{array}$ & $\begin{array}{l}\text { Developing PM } \\
\text { competency. } \\
\text { Training, coaching, } \\
\text { and mentoring of } \\
\text { PMs. }\end{array}$ & - & $\begin{array}{l}\text { Resource } \\
\text { management. } \\
\text { PMs employed in } \\
\text { PMO. }\end{array}$ & $\begin{array}{l}\text { Close monitoring } \\
\text { follow-up of } \\
\text { PMs. }\end{array}$ & Program managers \\
\hline
\end{tabular}




\begin{tabular}{|c|c|c|c|c|c|c|c|}
\hline $\begin{array}{l}\text { Isola et al. } \\
\qquad(2006)\end{array}$ & - & $\begin{array}{l}\text { Implementing } \\
\text { standard PM } \\
\text { methodology. }\end{array}$ & $\begin{array}{l}\text { Providing PM } \\
\text { training. }\end{array}$ & $\begin{array}{l}\text { Alignment with } \\
\text { business } \\
\text { objectives. }\end{array}$ & - & - & PPM. \\
\hline Julian (2008) & $\begin{array}{l}\text { Conducting } \\
\text { lessons-learnt } \\
\text { sessions. } \\
\text { Housing lessons- } \\
\text { learnt. }\end{array}$ & - & $\begin{array}{l}\text { Formal training of } \\
\text { PMs and team } \\
\text { members. }\end{array}$ & - & Personnel selection. & $\begin{array}{l}\text { Status reporting. } \\
\text { Intervening to } \\
\text { improve } \\
\text { troubled } \\
\text { projects. }\end{array}$ & - \\
\hline Koria (2009) & $\begin{array}{l}\text { Establishing a } \\
\text { knowledge } \\
\text { management } \\
\text { system. } \\
\text { Document evidence } \\
\text { from previous } \\
\text { projects. }\end{array}$ & - & $\begin{array}{l}\text { Staff training in } \\
\text { technical and } \\
\text { management skills. }\end{array}$ & $\begin{array}{l}\text { Negotiating with } \\
\text { key } \\
\text { stakeholders. }\end{array}$ & - & - & - \\
\hline $\begin{array}{l}\text { Kropf and } \\
\text { Scalzi, } \\
\text { (2008) }\end{array}$ & - & $\begin{array}{l}\text { Developing and } \\
\text { disseminating a } \\
\text { PM methodology. }\end{array}$ & $\begin{array}{l}\text { Disseminate and } \\
\text { provide education } \\
\text { and consultation on } \\
\text { PM methodology. }\end{array}$ & - & $\begin{array}{l}\text { Providing projects } \\
\text { with PMs. }\end{array}$ & $\begin{array}{l}\text { Monitoring and } \\
\text { reporting } \\
\text { project } \\
\text { performance. }\end{array}$ & $\begin{array}{l}\text { Helping senior } \\
\text { management } \\
\text { to prioritize } \\
\text { projects. }\end{array}$ \\
\hline $\begin{array}{l}\text { Lavoie- } \\
\text { Tremblay } \\
\text { et al. } \\
\text { (2012) }\end{array}$ & $\begin{array}{l}\text { Knowledge brokers } \\
\text { that gather data } \\
\text { and provide } \\
\text { projects with } \\
\text { information. }\end{array}$ & $\begin{array}{l}\text { Providing structure } \\
\text { and direction } \\
\text { through PM plans. }\end{array}$ & $\begin{array}{l}\text { Providing expertise } \\
\text { and supporting } \\
\text { project teams. }\end{array}$ & - & $\begin{array}{l}\text { Identifying and } \\
\text { selecting } \\
\text { individuals (PMs) } \\
\text { to lead project } \\
\text { implementation. }\end{array}$ & - & - \\
\hline $\begin{array}{l}\text { Lee-Kelley } \\
\quad \text { et al. } \\
\quad(2014)\end{array}$ & $\begin{array}{l}\text { Data and knowledge } \\
\text { repository. }\end{array}$ & $\begin{array}{l}\text { Formal systems and } \\
\text { processes. }\end{array}$ & $\begin{array}{l}\text { Providing specialized } \\
\text { expertise to } \\
\text { individual projects. }\end{array}$ & - & - & $\begin{array}{l}\text { Independent } \\
\text { project health } \\
\text { audits. }\end{array}$ & - \\
\hline $\begin{array}{l}\text { Liu and } \\
\text { Yetton } \\
(2007)\end{array}$ & $\begin{array}{l}\text { Knowledge } \\
\text { management } \\
\text { through sharing } \\
\text { good practice. }\end{array}$ & $\begin{array}{l}\text { Maintain and update } \\
\text { PMmethodologies } \\
\text { and standards. }\end{array}$ & $\begin{array}{l}\text { Conduct } \\
\text { benchmarking and } \\
\text { training. }\end{array}$ & $\begin{array}{l}\text { Align projects } \\
\text { with business } \\
\text { strategies. }\end{array}$ & - & $\begin{array}{l}\text { Conducting } \\
\text { project reviews } \\
\text { to control } \\
\text { quality, } \\
\text { progress and } \\
\text { cost. }\end{array}$ & $\begin{array}{l}\text { Coordinating all } \\
\text { projects } \\
\text { undertaken by } \\
\text { the } \\
\text { organization. } \\
\text { Maintaining a } \\
\text { balanced } \\
\text { project } \\
\text { portfolio. }\end{array}$ \\
\hline
\end{tabular}


Appendix: Continued.

\begin{tabular}{|c|c|c|c|c|c|c|c|}
\hline & $\begin{array}{l}\text { Lessons-learnt } \\
\text { database }\end{array}$ & $\begin{array}{l}\text { PM standards and } \\
\text { methods }\end{array}$ & $\begin{array}{l}\text { Consulting and } \\
\text { education }\end{array}$ & $\begin{array}{c}\text { Strategic } \\
\text { management }\end{array}$ & $\begin{array}{l}\text { Project resource } \\
\text { management }\end{array}$ & $\begin{array}{l}\text { Monitoring and } \\
\text { controlling }\end{array}$ & PPM \\
\hline $\begin{array}{l}\text { Martin et al. } \\
\text { (2007) }\end{array}$ & - & $\begin{array}{l}\text { Establish PM } \\
\text { methods and } \\
\text { procedures. }\end{array}$ & $\begin{array}{l}\text { Provide education, } \\
\text { training and } \\
\text { consulting. }\end{array}$ & - & - & - & $\begin{array}{l}\text { Formalized and } \\
\text { consistent } \\
\text { project } \\
\text { selection. } \\
\text { Coordination of } \\
\text { multiple } \\
\text { projects. }\end{array}$ \\
\hline $\begin{array}{l}\text { Monteiro de } \\
\text { Carvalho, } \\
\text { (2013) }\end{array}$ & $\begin{array}{l}\text { Managing project } \\
\text { knowledge } \\
\text { database. }\end{array}$ & $\begin{array}{l}\text { Develop and } \\
\text { maintain a set of } \\
\text { standards and } \\
\text { methods. Monitor } \\
\text { compliance with } \\
\text { organizational PM } \\
\text { methods }\end{array}$ & $\begin{array}{l}\text { Providing consulting } \\
\text { and mentoring in } \\
\text { the PM field. }\end{array}$ & $\begin{array}{l}\text { Representing a } \\
\text { bridgebetween } \\
\text { the } \\
\text { organization's } \\
\text { strategy and } \\
\text { projects. }\end{array}$ & - & $\begin{array}{l}\text { Collecting data } \\
\text { from projects, } \\
\text { consolidating } \\
\text { and reporting } \\
\text { to internal and } \\
\text { external } \\
\text { stakeholders. }\end{array}$ & - \\
\hline $\begin{array}{l}\text { Müller, } \\
\text { Glücker, } \\
\text { and Aubry } \\
\text { (2013) }\end{array}$ & $\begin{array}{l}\text { Partnering role: } \\
\text { Knowledge sharing } \\
\text { and joint } \\
\text { learning. }\end{array}$ & $\begin{array}{l}\text { Controlling role: } \\
\text { Enforcement of PM } \\
\text { tools, standards, } \\
\text { and methods. }\end{array}$ & $\begin{array}{l}\text { Serving role: } \\
\text { Training and } \\
\text { consulting. }\end{array}$ & - & $\begin{array}{l}\text { Controlling role: } \\
\text { Assessment of } \\
\text { employee } \\
\text { performance and } \\
\text { career promotion. }\end{array}$ & $\begin{array}{l}\text { Controlling role: } \\
\text { Evaluation of } \\
\text { project } \\
\text { performance. }\end{array}$ & - \\
\hline $\begin{array}{l}\text { Müller, } \\
\text { Glücker, } \\
\text { Aubry et al. } \\
\text { (2013) }\end{array}$ & $\begin{array}{l}\text { Collection and } \\
\text { dissemination of } \\
\text { project-related } \\
\text { knowledge and } \\
\text { information. }\end{array}$ & $\begin{array}{l}\text { Definition and } \\
\text { development of } \\
\text { practices and } \\
\text { methods. }\end{array}$ & $\begin{array}{l}\text { Administration of } \\
\text { internal certification } \\
\text { program for PMs. }\end{array}$ & - & $\begin{array}{l}\text { Provision of steering } \\
\text { committee and } \\
\text { escalation } \\
\text { functions. } \\
\text { Project manager } \\
\text { assignment. }\end{array}$ & - & $\begin{array}{l}\text { Selection, } \\
\text { authorizing } \\
\text { and validating } \\
\text { projects. }\end{array}$ \\
\hline $\begin{array}{l}\text { Pemsel and } \\
\text { Wiewiora } \\
\text { (2013) }\end{array}$ & $\begin{array}{l}\text { Provide a repository } \\
\text { for lessons learnt. }\end{array}$ & $\begin{array}{l}\text { Responsible for } \\
\text { project standard } \\
\text { and procedures. }\end{array}$ & $\begin{array}{l}\text { Active knowledge } \\
\text { sharing. } \\
\text { Training, workshops, } \\
\text { and seminars. } \\
\text { Formal and informal } \\
\text { social interactions. }\end{array}$ & - & $\begin{array}{l}\text { Ensure that projects } \\
\text { have a proper } \\
\text { allocation of } \\
\text { resources. }\end{array}$ & $\begin{array}{l}\text { Control and } \\
\text { quality } \\
\text { assurance. }\end{array}$ & - \\
\hline
\end{tabular}




\begin{tabular}{|c|c|c|c|c|c|c|c|}
\hline $\begin{array}{l}\text { Rozenes and } \\
\text { Vitner, } \\
\text { (2009) }\end{array}$ & - & $\begin{array}{l}\text { Defining and } \\
\text { maintaining the } \\
\text { standards of PM } \\
\text { processes. } \\
\text { Source of established } \\
\text { procedures, } \\
\text { documentation, } \\
\text { guidance and } \\
\text { metrics for PM. }\end{array}$ & - & - & $\begin{array}{l}\text { Assembles project } \\
\text { team and identifies } \\
\text { needed resources. }\end{array}$ & $\begin{array}{l}\text { Ensuring project } \\
\text { requirements } \\
\text { are achieved } \\
\text { within time and } \\
\text { budget. }\end{array}$ & - \\
\hline $\begin{array}{l}\text { Singh etal. } \\
\text { (2009) }\end{array}$ & $\begin{array}{l}\text { Knowledge } \\
\text { management. } \\
\text { Acting as a project } \\
\text { information } \\
\text { repository. }\end{array}$ & $\begin{array}{l}\text { Setting standards for } \\
\text { project } \\
\text { implementation. }\end{array}$ & $\begin{array}{l}\text { Providing PMs with } \\
\text { training, guidance } \\
\text { and consulting. }\end{array}$ & - & $\begin{array}{l}\text { PMs are employed in } \\
\text { PMO and loaned } \\
\text { out to various } \\
\text { projects. }\end{array}$ & - & - \\
\hline Spalek (2012) & $\begin{array}{l}\text { Access to historical } \\
\text { data and lessons- } \\
\text { learnt. }\end{array}$ & $\begin{array}{l}\text { Setting up and } \\
\text { enforcing PM } \\
\text { standards and } \\
\text { methodologies. }\end{array}$ & - & - & $\begin{array}{l}\text { Project managers } \\
\text { career path. }\end{array}$ & $\begin{array}{l}\text { Gathering } \\
\text { information } \\
\text { and data on } \\
\text { project status. } \\
\text { Supervising the } \\
\text { costs of } \\
\text { running } \\
\text { projects. }\end{array}$ & $\begin{array}{l}\text { PPM. } \\
\text { Prioritization of } \\
\text { projects. }\end{array}$ \\
\hline $\begin{array}{l}\text { Spelta and } \\
\text { Albertin } \\
\text { (2012) }\end{array}$ & $\begin{array}{l}\text { Facilitate transfer of } \\
\text { PM knowledge } \\
\text { across the } \\
\text { organization. }\end{array}$ & $\begin{array}{l}\text { Attention to best PM } \\
\text { practices. }\end{array}$ & - & $\begin{array}{r}\text { Implement } \\
\text { strategic } \\
\text { projects. }\end{array}$ & $\begin{array}{l}\text { Efficient use of } \\
\text { resources. }\end{array}$ & $\begin{array}{l}\text { Project status } \\
\text { control. }\end{array}$ & - \\
\hline $\begin{array}{l}\text { Taylor etal. } \\
\text { (2012) }\end{array}$ & - & $\begin{array}{l}\text { Developing PM } \\
\text { standard processes } \\
\text { including risk } \\
\text { assessment } \\
\text { process. }\end{array}$ & $\begin{array}{l}\text { PMO staff works with } \\
\text { local PMs in } \\
\text { implementing } \\
\text { standard processes. } \\
\text { Giving } \\
\text { recommendations } \\
\text { to projects. }\end{array}$ & - & - & $\begin{array}{l}\text { Formal quality } \\
\text { assurance. } \\
\text { Provide project } \\
\text { status to high- } \\
\text { level } \\
\text { stakeholders. }\end{array}$ & - \\
\hline $\begin{array}{l}\text { Thiry and } \\
\text { Deguire } \\
\text { (2007) }\end{array}$ & - & $\begin{array}{l}\text { Developing } \\
\text { standardized PM } \\
\text { practices and } \\
\text { methodologies. }\end{array}$ & $\begin{array}{l}\text { Developing PM } \\
\text { competencies. }\end{array}$ & $\begin{array}{l}\text { Managing the } \\
\text { strategic link. }\end{array}$ & $\begin{array}{l}\text { Allocating resources } \\
\text { across the } \\
\text { organization. }\end{array}$ & $\begin{array}{l}\text { Monitoring and } \\
\text { controlling } \\
\text { project } \\
\text { performance. }\end{array}$ & $\begin{array}{l}\text { Programme/ } \\
\text { portfolio } \\
\text { management. }\end{array}$ \\
\hline
\end{tabular}


Appendix:

Continued.

\begin{tabular}{|c|c|c|c|c|c|c|c|}
\hline & $\begin{array}{l}\text { Lessons-learnt } \\
\text { database }\end{array}$ & $\begin{array}{l}\text { PM standards and } \\
\text { methods }\end{array}$ & $\begin{array}{l}\text { Consulting and } \\
\text { education }\end{array}$ & $\begin{array}{c}\text { Strategic } \\
\text { management }\end{array}$ & $\begin{array}{c}\text { Project resource } \\
\text { management }\end{array}$ & $\begin{array}{l}\text { Monitoring and } \\
\text { controlling }\end{array}$ & PPM \\
\hline $\begin{array}{l}\text { Turner and } \\
\text { Lee-Kelley } \\
\text { (2013) }\end{array}$ & $\begin{array}{l}\text { Lessons learnt } \\
\text { procedure. }\end{array}$ & $\begin{array}{l}\text { Repository of } \\
\text { corporate project } \\
\text { standards and } \\
\text { methods. }\end{array}$ & $\begin{array}{l}\text { Responsible for } \\
\text { transferring best } \\
\text { practice to projects. }\end{array}$ & $\begin{array}{l}\text { Linking } \\
\text { corporate } \\
\text { strategy to } \\
\text { project } \\
\text { execution. }\end{array}$ & - & - & $\begin{array}{l}\text { Project } \\
\text { oversight, } \\
\text { coordination } \\
\text { and } \\
\text { governance. }\end{array}$ \\
\hline $\begin{array}{l}\text { Unger et al. } \\
\text { (2012) }\end{array}$ & $\begin{array}{l}\text { Supporting role: } \\
\text { improve } \\
\text { knowledge } \\
\text { transfer between } \\
\text { projects. } \\
\text { Post-project reviews } \\
\text { and lessons- } \\
\text { learnt. }\end{array}$ & $\begin{array}{l}\text { Supporting role: } \\
\text { Cultivating PM } \\
\text { standards. }\end{array}$ & - & $\begin{array}{l}\text { Enforcing the } \\
\text { firm's strategy } \\
\text { through the } \\
\text { project } \\
\text { portfolio. }\end{array}$ & $\begin{array}{l}\text { Coordinating role: } \\
\text { resource } \\
\text { allocation. }\end{array}$ & $\begin{array}{l}\text { Controlling role: } \\
\text { Monitoring } \\
\text { progress of } \\
\text { projects. }\end{array}$ & $\begin{array}{l}\text { Coordinating } \\
\text { role: accepting } \\
\text { projects into } \\
\text { the portfolio. } \\
\text { Reprioritizing } \\
\text { projects in the } \\
\text { portfolio. }\end{array}$ \\
\hline
\end{tabular}

